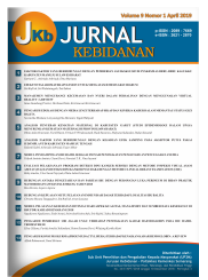

Volume 11 Nomor 2 (2021) 119-125

JURNAL KEBIDANAN

p-ISSN: 2089-7669 ; e-ISSN: 2621-2870

http://dx.doi.org/10.31983/jkb.v11i2.7519

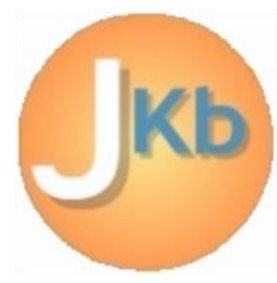

\title{
Behaviors Applying Health Protocols to Breastfeeding Mothers Who Have Been Vaccinated and Who Have Not Been Vaccinated Covid-19
}

\author{
Ulfatul Latifah $\left.{ }^{1 *}\right)$ Riska Arsita ${ }^{1}$ \\ ${ }^{1}$ Department of Midwifery, Polteknik Harapan Bersama Tegal,, Indonesia \\ Jl. Mataram No.9 Pesurungan Lor Kota Tegal, Jawa Tengah, Indonesia \\ Corresponding author: Ulfatul Latifah \\ Email: ulfatul.bidan@poltektegal.ac.id
}

Received: August $5^{\text {th }}, 2021$; Revised: September $7^{\text {th }}, 2021$; Accepted: October $13^{\text {th }}, 2021$

\begin{abstract}
In Indonesia, covid-19 through middle December 2020, there are over 600 thousand confirmed cases with a death toll over 16 thousand. Some of Indonesia's covid-19 pandemic efforts include prevention measures with the application of health protocols such as walking distance, washing your hands with soap and wearing a mask, vaccinating covid-19, and 3t (tests, calls, follow-up). The purpose of this research is to determine behavioural differences of health protocol at mothers breast-feeding that have been and have not been given from the covid19 vaccination. The study was conducted online through Google form in the Margadana city of Tegal, with the subjects of this study are 42 breastfeeding mothers with purposive sampling techniques. This research was quantitative which used observational with the cross sectional approach. The statistical test used by Mc Nemar to identify the difference in behavior implementing health protocols to breastfeeding mothers who have been vaccinated and who have not been vaccinated covid-19. The finding shows there was a behavioral difference in the application of the $3 \mathrm{M}$ health protocol on the mothers breast-feeding who had been vaccinated and had not been vaccinated covid-19 with exact sig values. It is expected that the city's government will be even more firm to sanction communities that violate the health protocol in countermeasure covid-19.
\end{abstract}

Keywords : behavior; vaccination covid19, breastfeeding mothers

\section{Pendahuluan}

Pandemi Covid-19 berdampak pada aspek kesehatan, ekonomi, dan sosial masyarakat. Hampir semua negara di dunia terdampak pandemi ini. Sampai dengan pertengahan Desember tahun 2020, secara global terdapat lebih dari 70 juta kasus Covid-19 dengan angka kematian lebih dari 1,5 juta jiwa. Di Indonesia Sejak kasus pertama Covid19 diumumkan pada tanggal 2 Maret 2020, sampai dengan pertengahan Desember 2020 terdapat lebih dari 600 ribu kasus terkonfirmasi dengan angka kematian lebih dari 16 ribu jiwa [1].

Corona virus adalah suatu kelompok virus yang dapat menyebabkan penyakit pada hewan atau manusia. Beberapa jenis corona virus diketahui menyebabkan infeksi saluran nafas pada manusia mulai dari batuk pilek hingga yang lebih serius seperti Middle East Respiratory Syndrome (MERS) dan Severe Acute Respiratory Syndrome (SARS). Corona virus jenis baru yang ditemukan menyebabkan penyakit Covid-19 yaitu SARS-CoV2. Corona Virus Disease 2019 yang selanjutnya disebut Covid-19 adalah penyakit menular yang disebabkan oleh Severe Acute Respiratory Syndrom Coronavirus 2 (SARSCoV-2) [2].

Gejala-gejala yang dialami biasanya bersifat ringan dan muncul secara bertahap. Namun ada juga orang yang sudah terkena virus tetapi tidak merasakan gejala apapun dan tetap merasa sehat. Gejala-gejala Covid-19 yang paling umum adalah demam, batuk kering, dan rasa lelah. Gejala 
lainnya yang lebih jarang dan mungkin dialami beberapa pasien meliputi rasa nyeri dan sakit, hidung tersumbat, sakit kepala, konjungtivitis, sakit tenggorokan, diare, kehilangan indra rasa atau penciuman, ruam pada kulit, atau perubahan warna jari tangan atau kaki [2].

Vaksinasi adalah pemberian Vaksin yang khusus diberikan dalam rangka menimbulkan atau meningkatkan kekebalan seseorang secara aktif terhadap suatu penyakit, sehingga apabila suatu saat terpajan dengan penyakit tersebut tidak akan sakit atau hanya mengalami sakit ringan dan tidak menjadi sumber penularan [3]. Tujuan utama vaksinasi Covid-19 adalah mengurangi transmisi/penularan Covid-19, menurunkan angka kesakitan dan kamatian akibat Covid-19. Mencapai kekebalan kelompok di masyarakat (herd imunity) dan melindungi masyarakat dari Covid-19 agar tetap produktif secara sosial dan ekonomi [3]. Vaksinasi Covid-19 adalah bagian penting dari upaya penanganan pandemi Covid-19 yang menyeluruh dan terpadu meliputi aspek pencegahan dengan penerapan protokol kesehatan: menjaga jarak, mencuci tangan pakai sabun dan memakai masker (3M), vaksinasi Covid-19, dan 3T (Tes, Telusur, Tindak lanjut) [4].

Hasil studi yang dilakukan Badan Pusat Statistik dan Satuan Tugas Penanganan Covid-19 pada bulan September 2020 menunjukkan 75\% masyarakat mencuci tangan pakai sabun, $92 \%$ memakai masker dan $73 \%$ menjaga jarak. Penerapan protokol kesehatan yang konsisten memerlukan kebijakan yang mendukung, sarana dan prasana yang memadai serta edukasi dan komunikasi perubahan perilaku yang dapat menjangkau seluruh lapisan masyarakat dengan informasi yang mudah dipahami, akurat, menarik, dan dapat mendorong terjadinya adopsi perilaku pencegahan [5].

Hasil survei penerimaan vaksin yang dilakukan Kementerian Kesehatan bersama ITAGI (Indonesian Technical Advisory Group on Immunization) dengan dukungan UNICEF dan WHO pada bulan September 2020 menunjukkan bahwa sebagian besar masyarakat (74\%) sudah mengetahui rencana pemerintah untuk melaksanakan vaksinasi Covid-19. Sebanyak 65\% bersedia untuk divaksinasi, sekitar $27 \%$ masih ragu. Dan hanya sebagian kecil atau sekitar 8 persen yang menyatakan menolak dengan alasan khawatir akan keamanan, efektivitas dan kehalalan vaksin. Hasil survei juga menunjukkan bahwa mereka yang memiliki informasi tentang vaksinasi Covid-19 cenderung lebih menerima [6].
Penelitian lain menyebutkan bahwa berdasarkan 3 indikator dalam penerapan protokol kesehatan didapatkan hasil sebanyak 176 responden $(76,5 \%)$ telah melaksanakan penerapan protokol kesehatan dengan metode $3 \mathrm{M}$ antara lain terdapat sebanyak $218(94,8 \%)$ telah menerapkan cuci tangan menggunakan sabun dan air mengalir, menjaga jarak (physical distancing) sebanyak 185 responden $(80,4 \%)$, dan sebanyak 225 responden $(97,8 \%)$ telah menggunakan masker [7].

Ibu menyusui merupakan salah satu kelompok rentan terpapar Covid-19, ibu menyusui yang terkena infeksi virus Corona masih boleh memberikan ASI atau menyusui bayinya. Meski demikian, risiko bayi tertular infeksi virus Corona dari ibunya tetap ada jika ibu tidak menggunakan APD (alat pelindung diri). Penularan bisa terjadi ketika ibu menyusui yang terjangkit virus Corona menyentuh bayinya dengan tangan yang belum dicuci, juga ketika ibu menyusui batuk atau bersin di dekat bayinya. Dengan demikian pemberian vaksin dan penerapan protokol kesehatan dan sangat penting untuk ibu menyusui seperti: cuci tangan memakai sabun selama 20 detik atau hand sanitizer, pemakaian alat pelindung diri (masker kain), menjaga kondisi tubuh dengan rajin olah raga dan istirahat cukup, makan dengan gizi yang seimbang, dan mempraktikan etika batuk-bersin [8].

Puskesmas Sumurpanggang merupakan instansi pelayanan kesehatan yang berada di Wilayah Kecamatan Margadana Kota Tegal yang telah memberikan pelayanan vaksinasi covid 19 yang dimulai pada bulan januari sampai bulan maret 2021 sudah lebih dari seribu orang yang telah diberikan vaksin Covid 19. Vaksinasi covid diberikan tahap pertama pada nakes (tenaga kesehatan), kemudian disususl pelayanan public, lansia, termasuk ibu menyusui yang merupakan kelompok beresiko baik yang berada dipelayanan kesehatan atau pelayanan publik.

Berdasarkan latar belakang masalah dan melihat situasi saat ini kasus covid-19 yang terus meningkat maka berbagai upaya yang dilakukan oleh pemerintah seperti pemberlakuan PPKM darurat, pemberian vaksin masal dan sebagainya namun masih banyak masyarkat ditempat umum yang mengabaikan protokol kesehatan, khusus nya untuk ibu menyusui yang merupakan kelompok rentan terpapar covid-19 dengan demikian peneliti tertarik melakukan penelitian yang bertujuan untuk mengetahui bagaimanakah perilaku penerapan protokol kesehatan pada ibu menyusui yang sudah divaksinasi Covid-19 dan yang belum divaksinasi Covid-19. Apakah terdapat perbedaan perilaku pada 
masyarakat tersebut khusus nya ibu menyusui di kecamatan Margadana Kota Tegal.

\section{Metode Penelitian}

Jenis penelitian ini adalah analitik menggunakan desain penelitian observasi dengan pendekatan cross sectional. Tujuan dari penelitian ini adalah menentukan adanya perbedaan perilaku penerapan protokol kesehatan pada ibu menyusui yang sudah divaksinasi dan yang belum divaksinasi. Populasi dalam penelitian ini adalah ibu menyusui yang ada di Wilayah Margadana Kota Tegal.
Sampel dalam penelitian ini adalah ibu menyusui sejumlah 42 orang dengan teknik pengambilan sampel secara purposive sampling. Dalam penelitian ini analisis data yang dilakukan adalah analisis univariat untuk menghasilkan distribusi frekuensi dan presentasi dari tiap variabel. Sedangkan analisis bivariate membandingkan distribusi silang antara dua variabel yang bersangkutan dengan menggunakan uji analisis Mc.Nemar. Surat layak etik dikeluarkan oleh komisi etik penelitian Poltekkes Kemenkes Semarang dengan nomor etik No. 170/EA/KEPK/2021.

\section{Hasil dan Pembahasan}

\section{Tabel 1.}

\section{Krakateristik responden}

\begin{tabular}{llll}
\hline No & Karakteristik & F & $\%$ \\
\hline 1 & Umur ibu & & \\
& 20-35tahun & 34 & 81 \\
& >35 tahun & 8 & 19 \\
2 & Umur bayi & & \\
& <6 bulan & 16 & 38,1 \\
& 6-12 bulan & 14 & 33,3 \\
& 13-24 bulan & 12 & 28,6 \\
3 & Pendidikan & & \\
& SD-SMP & 4 & 9,5 \\
& SMA & 16 & 38,1 \\
& Perguruan Tinggi & 22 & 52,4 \\
& Paritas & & 38,1 \\
& 1 kali & 16 & 54,8 \\
& 2-4 kali & 23 & 7,1 \\
& >4 kali & 4 & 45,2 \\
& Pekerjaan & & 54,8 \\
\hline
\end{tabular}

Tabel 2.

Perilaku Prokes dan Pemberian Vaksin Covid-19

\begin{tabular}{llll}
\hline No & Keterangan & F & $\%$ \\
\hline 1 & Perilaku Prokes & 33 & 78,6 \\
& Tidak patuh & 9 & 21,4 \\
& Patuh & & \\
2 & Vaksin covid-19 & 19 & 45,2 \\
& Sudah & 23 & 54,8 \\
\hline
\end{tabular}


Tabel 3.

Perilaku Penerapan Prokes pada responden yang sudah divaksinasi dan yang belum divaksinasi Covid-19

\begin{tabular}{|c|c|c|c|c|c|}
\hline \multirow{2}{*}{ No } & \multirow{2}{*}{ Perilaku } & \multicolumn{2}{|c|}{ Vaksin Covid-19 } & \multirow[t]{2}{*}{ Total } & \multirow[t]{2}{*}{ Exact Sig. (2-tailed } \\
\hline & & Sudah & Belum & & \\
\hline 1 & Tidak patuh & $16(48,5 \%)$ & $\begin{array}{c}17 \\
(51,5 \%)\end{array}$ & $\begin{array}{c}33 \\
(100 \%)\end{array}$ & 0,003 \\
\hline 2 & Patuh & $3(33,3 \%)$ & $6(66,7 \%)$ & $9(100 \%)$ & \\
\hline
\end{tabular}

Penelitian ini dilaksanakan di Kota Tegal pada bulan juli 2021 secara online melalui google form. Dengan responden ibu menyusui sebanyak 42 orang.

Berdasarkan hasil penelitian pada tabel 1 karakteristik responden berdasarkan umur, pendidikan, pekerjaan menunjukkan sebagian besar responden berusia 20-35 tahun sebanyak 34 (81\%), pendidikan diperguruan tinggi sebanyak $22(52,4 \%)$ dan bekerja sebanyak $23(54,2 \%)$. Data pemantauan Covid-19 di Jakarta pada 9 September 2020 memperlihatkan, rentang usia 30-39 tahun menjadi yang tertinggi dengan kasus 11.707 orang, lalu rentang usia 20-29 tahun di urutan kedua terbanyak dengan kasus 10.089 orang. Melihat data tersebut sebagian besar pasien positif covid di Jakarta berasal dari kelompok usia produktif [9].

Hal ini kemungkinan disebabkan karena pada usia 20-35 tahun dan aktif bekerja memiliki gaya hidup yang lebih dinamis dengan tingkat sosialisasi yang juga tinggi. Meraka kerap berkumpul dan berdiskusi untuk menyelesaikan sebuah pekerjaan di kantor. Kemudian di jam istirahat dan setelah jam kerja salah satu cara untuk melepas keletihan adalah dengan mengunjungi kafe atau restoran terdekat. Kegiatan yang dulu merupakan sebuah rutinitas pada masa normal, kini berisiko penularan di kala pandemi. Selain itu masih banyak orang yang beranggapan bahwa mereka yang berusia muda lebih tahan terhadap Covid-19, namun pada kenyataannya hal ini ikut berkontribusi terhadap jumlah infeksi di kalangan usia produktif, orang yang berpendidikan tinggi dan bekerja.

Hasil penelitian lain yang dilakukan di wilayah Sulawesi Tenggara menyatakan bahwa usia tidak berhubungan dengan persepsi individu tentang vaksin covid-19 (p-value=0.218), dan jenis pekerjaan tidak berhubungan dengan kesediaan untuk divaksinasi covid-19 (p-value $=0.091)$ sedangkan berdasakan pendidikan sebagian besar besar responden yang mempunyai persepsi yang cukup baik yaitu berstatus sarjana, dan yang kedua berstatus mahasiswa [10].

Berdasarkan tabel 2 menunjukkan Perilaku penerapan protokol kesehatan $3 \mathrm{M}$ responden sebagian besar tidak patuh sebanyak $33(78,6 \%)$. Berdasarkan hasil survai perilaku masyarakat dimasa pandemi covid-19 oleh Badan Pusat Statistik menunjukan tingkat kepatuhan responden dalam pencegahan covid-19 sudah baik sedangkan alasan masyarakat yang tidak patuh dalam penerapan protokol kesehatan sebagian besar (59\%) menyebutkan karena tidak ada sanksi jika tidak menerapkan protokol kesehatan [5].

Masyarakat memiliki peran penting dalam memutus mata rantai penularan covid-19 agar tidak menimbulkan sumber penularan baru. Mengingat cara penularannya berdasarkan droplet infection dari individu ke individu, maka penularan dapat terjadi baik di rumah, maupun diluar rumah. Untuk itu pencegahan penularan covid-19 pada level individu dan level masyarakat dilakukan dengan beberapa tindakan, seperti membersihkan tangan secara teratur dengan mencuci tangan, menggunakan alat pelindung diri berupa masker dan menjaga jarak minimal 1 meter dengan orang lain yang biasa dikenal dengan program 3M. Selain itu juga melakukan memberikan desinfektan secara berkala pada benda- benda yang sering disentuh dan pada permukaan rumah dan perabot (meja, kursi, dan lainlain), gagang pintu, dan lain-lain serta Mengurangi berkunjung ke rumah kerabat/teman/saudara, mengurangi menerima kunjungan/tamu dan lain-lain [11].

Berdasarkan hasil penelitian sebagian besar responden belum divaksinasi covid-19 sebanyak 23 $(54,8 \%)$. Pemberian vaksinasi bertujuan untuk memberikan kekebalan spesifik terhadap suatu penyakit tertentu sehingga apabila suatu saat terpajan dengan penyakit tersebut maka tidak akan sakit atau hanya mengalami sakit ringan. Tentu, apabila seseorang tidak menjalani vaksinasi maka ia tidak akan memiliki kekebalan spesifik terhadap penyakit yang dapat dicegah dengan pemberian vaksinasi tersebut. Apabila cakupan vaksinasi tinggi dan merata di suatu daerah maka akan terbentuk kekebalan kelompok (herd immunity) [12]-[13].

Hasil survei penerimaan vaksin yang dilakukan Kementerian Kesehatan pada bulan 
September 2020 menunjukkan bahwa sebagian besar masyarakat (74\%) sudah mengetahui rencana pemerintah untuk melaksanakan vaksinasi COVID19. Sebanyak 65 persen bersedia untuk divaksinasi, sekitar 27 persen masih ragu, dan hanya sebagian kecil atau sekitar 8 persen yang menyatakan menolak dengan alasan khawatir akan keamanan, efektivitas dan kehalalan vaksin. Mereka yang memiliki informasi tentang vaksinasi COVID-19 cenderung lebih menerima [6].

Dalam upaya penanggulangan covid-19 pemerintah berupaya agar semua masyarakat dapat dilakukan divaksinasi covid-19 namun pada kenyataan nya masih banyak masyarakat yang belum divaksianasi terutama pada kelompok rentan terpapar covid-19 seperti ibu menyusui. Berdasarkan waktu pelaksanaan penerimaan vaksin pada tahap 3 dilaksanakan pada bulan april 2021maret 2022 sasaran sasarannya adalah masyarakat rentan dari aspek geospasial, sosial, dan ekonomi [12].

Penelitian ini berdasarkan tabel 3 bertujuan untuk menentukan adanya perbedaan perilaku terhadap penerapan protokol kesehatan $3 \mathrm{M}$ pada ibu menyusui yang sudah divaksinasi dan yang belum divaksinasi Covid-19. Penerapan protokol kesehatan yang dimaksud adalah dengan 3M yaitu menjaga jarak, mencuci tangan pakai sabun dan memakai masker (3M) berdasarkan table 4.3 menunjukkan terdapat $16(48,5 \%)$ responden yang sudah divaksinasi dan tidak patuh dalam penerapanan protokol kesehatan. Hasil analisis terdapat perbedaan perilaku dalam penerapan protokol kesehatan $3 \mathrm{M}$ pada ibu menyusui yang sudah divaksinasi dan belum divaksinasi covid-19 dengan nilai Exact Sig. (2-tailed) 0,003.

Hasil penelitian lain yang dilakukan pada warga Padukuhan Ngaliyan Tahun 2021 menyebutkan terdapat pengaruh yang signifikan antara media informasi terhadap perilaku $3 \mathrm{M}$ hal ini dibuktikan bahwa responden yang memiliki media informasi yang baik dan cukup akan berpengaruh terhadap perilaku $3 \mathrm{M}$ yang baik, begitu sebaliknya [14].

Hasil survei yang dilakukan Kementerian Kesehatan menunjukkan bahwa masyarakat yang memiliki informasi tentang vaksinasi covid-19 cenderung lebih menerima vaksinasi covid-19. Hal ini menunjukkan pentingnya untuk memastikan seluruh masyarakat mendapatkan akses terhadap informasi yang akurat tentang penanganan covid19, termasuk tentang vaksinasi covid-19. Sedangkan hasil survai kesediaan masyarakat untuk vaksinasi covid-19 di Sulawesi Tenggara menyatakan bahwa sebagian besar responden (66.2\%) telah menyatakan kesediaannya untuk divaksinasi dengan vaksin covid-19. Sementara masih ada sekitar $33.8 \%$ responden yang belum bersedia untuk divaksinasi dengan berbagai alasannya termasuk keraguhan dan juga keberadaan vaksin covid-19 itu sendiri [6],[10].

Berdasarkan hasil survai lain dipondok pesantren terhadap 500 orang santri menyebutkan terdapat $60 \%$ responden yang memahami cara pencegahan dan penanganan penularan covid-19 dan $40 \%$ mengetahui cara simulasi pemberlakukan protokol kesehatan 3M sedangkan permasalahan yang sering dihadapi selama masa pandemi ini adalah kurang patuhnya penerapan protokol kesehatan secara mandiri pada para santri.[15] Dengan demikian kegiatan edukasi dan sosialisasi tentang protokol kesehatan ini sebagai upaya pencegahan penularan Covid-19 berdampak baik pada peningkatan pengetahuan dan perilaku dalam upaya pencegahan penularan covid-19.

Prinsip-prinsip pencegahan/pemutusan rantai penularan COVID- 19 pada ibu hamil, ibu nifas dan bayi baru lahir di masyarakat meliputi universal precaution yaitu sama dengan pencegahan pada masyarakat umumnya dengan selalu cuci tangan memakai sabun selama 20 detik atau hand sanitizer, pemakaian alat pelindung diri (masker kain), menjaga kondisi tubuh dengan rajin olah raga dan istirahat cukup, makan dengan gizi yang seimbang, dan mempraktikan etika batuk-bersin, dan sebelum melakukan pemeriksaan kehamilan, persalinan dan nifas maka ibu harus membuat janji terlebih dahulu kepada bidan/dokter untuk kedatangan pemeriksaan, hal ini dimaksudkan agar ibu tidak terkontak dengan banyak orang di pelayanan kesehatan [8].

Pemberian vaksinasi covid-19 merupakan salah satu upaya pemerintah dalam penanggulangan kasus covid-19 di Indonesia. Selama cakupan vaksinasi belum luas, kekebalan kelompok belum terbentuk, potensi penularan masih tinggi oleh karena itu, sekalipun telah dilakukan vaksinasi, masyarakat tetap harus mematuhi dan menjalankan protokol kesehatan. Di sisi lain, Pemerintah tetap akan menggiatkan kegiatan 3T (Test, Tracing dan Treatment) untuk penanggulangan covid-19.[12] Vaksin bersama, penerapan disiplin 3M (Memakai Masker, Menjaga jarak, Mencuci tangan) dan penguatan 3T (Tracing, Testing, Treatment) merupakan upaya lengkap dalam menekan penyebaran covid-19 secara efektif. Masyarakat mempunyai peran penting untuk dapat memutus mata rantai penularan covid-19 (risiko tertular dan 
menularkan) yaitu dengan menerapkan protokol kesehatan dengan 3M yang meliputi: menggunakan masker, membersihkan tangan secara teratur dan menjaga jarak minimal 1 meter.

\section{Simpulan}

Perilaku penerapan protokol kesehatan responden sebagian besar tidak patuh sebanyak 33 $(78,6 \%)$ sedangkan pemberian vaksian sebagian besar responden belum divaksinasi covid-19 sebanyak $23(54,8 \%)$. Hasil analisis menunjukkan terdapat perbedaan perilaku dalam penerapan protokol kesehatan pada ibu menyusui yang sudah divaksinasi dan belum divaksinasi covid-19 dengan nilai Exact Sig. (2-tailed) 0,003. Diharapkan pemerintah kota Tegal lebih tegas lagi untuk memberikan sanksi pada masyarakat yang melanggar protokol kesehatan terutama di tempat tempat umum seperti pasar, mall, kendaraan umum dsb dalam rangka penanggulangan covid-19

\section{UcapanTerimakasih}

Terima kasih disampaikan kepada Politeknik Harapan Bersama yang telah mendukung berjalannya penelitian ini dalam penyediaan dana dan fasilitasi perizinan. Ucapan terima kasih juga disampaikan kepada Kepala Kepala Puskesmas Margadana yang telah memberikan ijin untuk melakukan penelitian di Kecamatan Margadana beserta ibu bidan dan kader yang sudah banyak membantu dalam penelitian ini.

\section{Daftar Pustaka}

[1] WHO, "WHO Coronavirus (Covid 19) Dashboard." 2020, [Online]. Available: https://covid19.who.int/.

[2] WHO, "Pertanyaan dan jawaban terkait COVID-19.” 2020, [Online]. Available: https://www.who.int/indonesia/news/novelcoronavirus/qa-hydroxychloroquine.

[3] Kemenkes RI, "Peraturan menteri kesehatan republik indonesia nomor 84 tahun 2020 tentang pelaksanaan vaksinasi dalam rangka penanggulangan pandemi," vol. 2019, 2020.

[4] Komite Penanggulangan Covid-19 dan Pemulihan Ekonomi Nasional, "Vaksinasi Covid-19 Lindungi Diri, Lindungi Negeri," Kementeri. Kesehat. RI, p. 22, 2021, [Online]. Available:

https://promkes.kemkes.go.id/paket-advokasivaksinasi-covid-19-lindungi-diri-lindungi- negeri.

[5] Tim BPS Covid-19 Statistical Task Force, Hasil Survei Perilaku Masyarakat Di Masa Pandemi Covid-19 (7-14 September 2020), vol. 19, no. September. 2020.

[6] Kementerian Kesehatan Republik Indonesia, ITAGI, WHO, and UNICEF, "Survei Penerimaan Vaksin COVID-19 di Indonesia," Satuan Gugus Tugas Penanganan COVID-19, no. November, 2020.

[7] B. M. Fitri, O. Widyastutik, and I. Arfan, "COVID-19," Ris. Inf. Kesehat., vol. 9, no. 2, pp. 143-153, 2020, doi: 10.30644/rik.v8i2.460.

[8] Y. Purnama, K. Dewiani, and L. Yusanti, "Pemutusan Rantai Penularan Covid-19 Pada Ibu Hamil, Nifas dan Menyusui di Kecamatan Ratu Agung Kota Bengkulu," Dharma Raflesia J. Ilm. Pengemb. dan Penerapan IPTEKS, vol. 18, no. 2, pp. 190-198, 2020, doi: 10.33369/dr.v18i2.13170.

[9] Aditya Gagat Hanggara, "Mengulik Usia Pasien Positif Covid-19 di Jakarta," 2020, [Online]. Available: https://corona.jakarta.go.id/id/artikel/menguli k-usia-pasien-positif-covid-19-di-jakarta.

[10] H. Tasnim, Persepsi Masyarakat tentang Vaksinasi Covid-19 di Wilayah Sulawesi Tenggara. Kendari: Yayasan Kita Menulis, 2020.

[11] at. al. Doni Monardo, Mohammad Subuh, Slamet, Akmal Taher,Tugas Ratmono, Amin Soebandrio, "Pedoman Penanganan Cepat Medis dan Kesehatan Masyarakat Covid-19 di Indonesia," 23 Maret, pp. 1-38, 2020, [Online].

Available: http://www.covid19.go.id

[12] Kementerian Kesehatan Republik Indonesia, "Question ( Faq ) Pelaksanaan Vaksinasi Covid-," 2020, pp. 1-16, 2021, [Online]. Available:

https://kesmas.kemkes.go.id/assets/uploads/co ntents/others/FAQ_VAKSINASI_COVID_c all_center.pdf.

[13] Permenkes RI KMK No. HK.01.07/MENKES/382/2020, "Corona virus disease 2019," Peratur. Menteri Kesehat. Republik Indones., vol. Nomor 9, no. Pedoman Pembatasan Sosial Berskala Besar dalam Rangka Percepatan Penanganan Corona Virus DIsease 2019 (COVID-19), pp. 2-6, 2020, [Online]. Available: http://jurnalrespirologi.org/index.php/jri/articl e/view/101. 
[14] R. Damayanti and A. , Dea Adelia, Winnie Tunggal Mutika, "FAKTOR YANG MEMPENGARUHI PERILAKU 3M DALAM PENCEGAHAN PENULARAN COVID - 19 DI PADUKUHAN NGALIYAN," J. Kesmas Untika Luwuk Public Heal. J., vol. 9, pp. 18-26, 2018,
[Online]. Available: https://journal.fkmuntika.ac.id/index.php/phj/article/view/59/50.

[15] D. Kuswoyu, "PENCEGAHAN PENULARAN COVID-19 DENGAN PEMBERLAKUAN PERILAKU 3M," $J$. Peduli Masy., vol. 3, pp. 123-128, 2021. 